\title{
Clavarioid fungi of the Urals. II. The nemoral zone
}

\author{
ANTON G. SHIRYAEV
}

SHIRYAEV, A. 2007: Clavarioid fungi of the Urals. II. The nemoral zone. - Karstenia 47: 5-16. 2007. Helsinki. ISSN 0453-3402.

One hundred and eighteen clavarioid species are reported from the nemoral zone of the Ural Mts.. Eight of them, Ceratellopsis aculeata, C. terrigena, Lentaria corticola, Pistillaria quercicola, Ramaria broomei, R. lutea, $R$. subtilis and Typhula hyalina, are reported for the first time from Russia. The material consists of 1300 collections and observations, and according to these, the most frequent species are Clavulina cinerea, Macrotyphula. juncea, Typhula erythropus, T. sclerotioides, T. uncialis and T. variabilis. These contain ca. $23 \%$ of all observations, but only $5 \%$ of all the species. In comparison with the boreal zone of the Urals, the nemoral zone consists less abundant species $(1.7 \%$ / 14.6\%) and an more rare species (47.8\% / 38.2\%). Species like Clavulinopsis aurantiocinnabarina, Pistillaria quercicola, Ramaria broomei, R. lutea and Sparassis brevipes are considered to be relicts of Pliocen and Holocen periods. The most favorable habitats for the rare and relict species are discussed. The collecting sites are briefly described and descriptions of the new and rare species for Russia are given.

Key words: Aphyllophorales, Basidiomycetes, clavarioid fungi, distribution, nemoral, relicts, Ural

Anton Shiryaev, Institute of Plant and Animal Ecology RAS, 8 March str. 202, 620144, Ekaterinburg, Russia

\section{Introduction}

The Northern subzone of the nemoral zone, like also the hemiboreal zone, are widely distributed in Central Europe but in easternmost Europe represented just as narrow strips on the western slopes of the South Ural Mountains (Sjörs 1963, Gorchakovsky 1968). Publications from the nemoral zone in several European countries list nearly 200 species of clavarioid fungi (Pilát 1958, Berthier 1976, Jülich 1984, Hansen \& Knudsen 1997, Franchi \& Marchetti 2001), but the information of this group from Ural Mountains (later abbreviated as Ural) and European part of the nemoral zone in Russia is fragmentary and rather meager (Potatosova 1960, Parmasto 1965, Stepanova-Kartavenko 1967, Bedenko 1985; Davidkina et al., 1989; Bondartseva et al., 1999; Dunaev \& Barsukova 1999; Spirin 2003; Hoshino et al., 2004). Until now only 43 species are reported from the European part of Russia, including 11 species from Ural. This paper is the second part of clavarioid fungi of Ural (see Shiryaev 2004) and is devoted to fungi associated mainly with the nemoral zone. The delimitation between the southern parts of hemiboreal zone and northern parts of nemoral zone is often extremely difficult, and in the area somewhat vague. However, most of the material treated here is apparently from nemoral zone or transitional areas between hemiboreal and nemoral zones.

\section{The study area}

The nemoral and hemiboreal zones in Ural are characterized by a continental climate. The lowest temperatures are $-37.1^{\circ} \mathrm{C}$, the mean annual temperature $2.5-3.5^{\circ} \mathrm{C}$ and the average January and July temperatures $-14^{\circ} \mathrm{C}$ and $19^{\circ} \mathrm{C}$, respectively. In summer, the temperature rises rapidly, exceeding $19^{\circ} \mathrm{C}$ in the first days of July, and the maximum temperature in July may reach $39.6^{\circ} \mathrm{C}$. The annual precipitation in the region ranges between $500-850 \mathrm{~mm}$, the rainiest seasons being in summer and early autumn. 
The areas studied include all typical natural communities of the nemoral and hemiboreal zones in the Urals (Gorchakovsky 1975). The material was collected in the following five localities (Fig. 1; Table 1). The first one (No. 1) is a mesic spruce (Picea abies) forest with elms (Ulmus laevis, U. scabra), maple (Acer platanoides), linden (Tilia cordata) and fir (Abies sibirica). Two of the localities (No. 2 and No. 4) are fir dominated herb-rich forest with linden, maple, elm and a few oaks (Quercus robur), and two (No. 3 and No. 5) herb rich oak forests with maple, elm and hazel (Corylus avellana).

Administratively the study areas belong to the Perm region (hemiboreal zone), Sverdlovsk region (northeastern part of hemiboreal zone), Chelyabinsk region and Bashkiria Republic (eastern part of nemoral zone) and Orenburg region (southeastern part of nemoral zone).
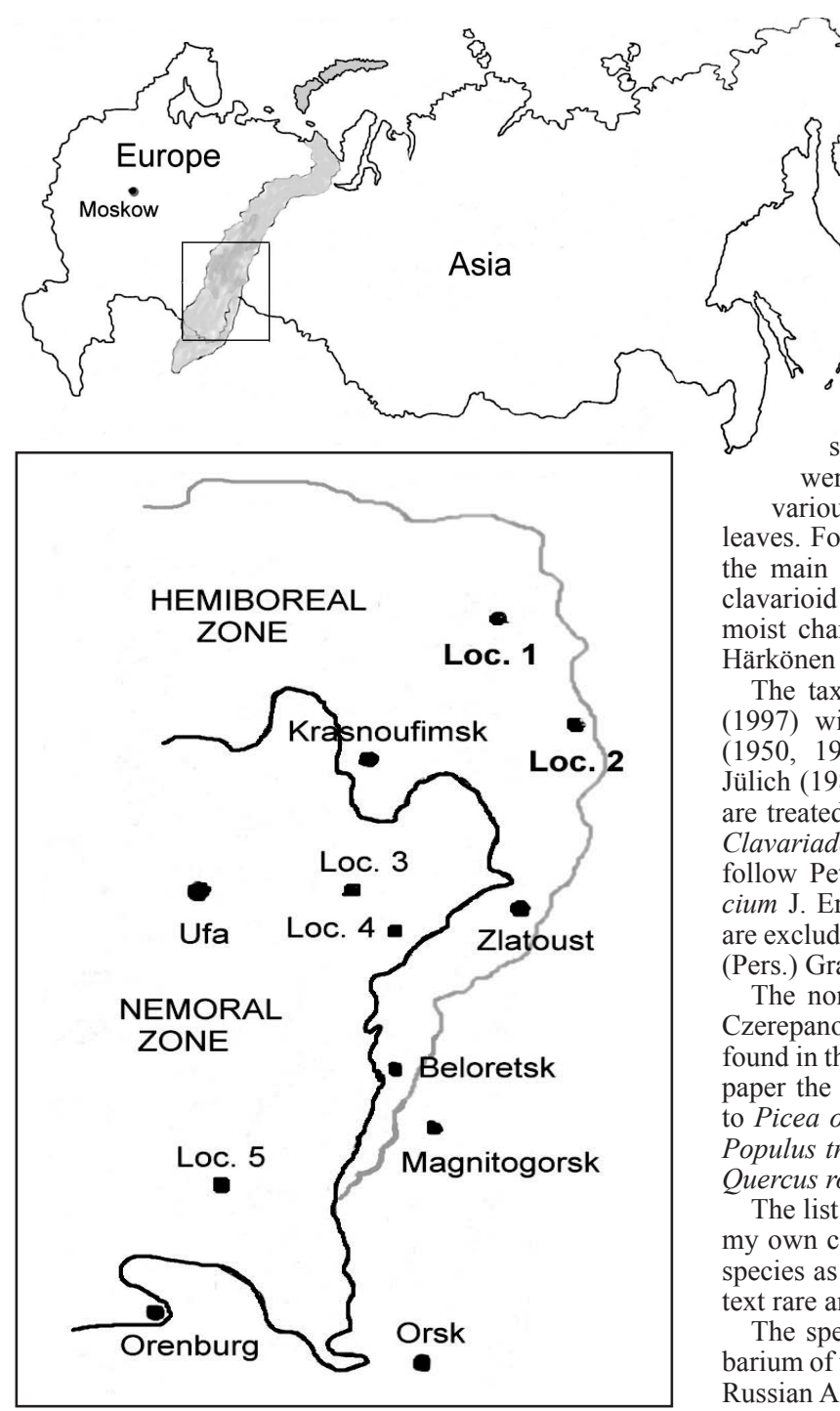

Fig. 1. Locations of the research area.

\section{Materials and methods}

The material was collected by the author during ten years (1996-2005). Most of the species were collected in the forests and some were obtained from moist chamber cultures of various substrata, especially from dead herbs and leaves. For each locality an effort was made to examine the main types of microhabitats where fruit bodies of clavarioid fungi might be expected. Nearly one hundred moist chamber cultures were prepared as described by Härkönen (1977) and maintained for one month.

The taxonomy mostly follows Hansen and Knudsen (1997) with some modifications according to Corner (1950, 1970), Parmasto (1965), Berthier (1976) and Jülich (1984). The genera Typhula Fr. and Pistillaria Fr. are treated according to Berthier (1976), and the genera Clavariadelphus Donk and Macrotyphula R.H. Petersen follow Petersen (1972). The corticioid genera Ramaricium J. Eriksson, Kavinia Pilát and Clavulicium Boidin are excluded, as well as the cantharelloid genus Gomphus (Pers.) Gray.

The nomenclature of vascular plants is according to Czerepanov (1995). The authors of species names are found in that publication and are not repeated here. In this paper the epithets "fir" refer to Abies sibirica, "spruce" to Picea obovata, "pine" to Pinus sylvestris, "aspen" to Populus tremula, "maple" to Acer platanoides, "oak" to Quercus robur and "elm" to Ulmus spp., respectively.

The list of species (Table 2 ) below is mostly based on my own collections and it shows the abundance of each species as well as the substrate(s) in each locality. In the text rare and new species to Russia are described.

The specimens are deposited in the mycological herbarium of the Institute of Plant and Animal Ecology of the Russian Academy of Sciences in Ekaterinburg (SVER). 
Table 1. Description of studied localities in the nemoral and hemiboreal zones of the Urals.

\begin{tabular}{|c|c|}
\hline № loc. & Description of localities \\
\hline 1 & $\begin{array}{l}\text { Sverdlovsk region }\left(57^{\circ} 22^{\prime} \mathrm{N}, 58^{\circ} 42^{\prime} \mathrm{E}\right) \text {. Shalya area ( } 320 \mathrm{~m} \text { above sea level). Spruce-rich herb forest with } \\
\text { Ulmus, Abies, Acer, Tilia, Sorbus, Betula, Padus. }\end{array}$ \\
\hline 2 & $\begin{array}{l}\left.\text { Sverdlovsk region }\left(56^{\circ} 39^{\prime} \mathrm{N}, 59^{\circ} 17^{\prime} \mathrm{E}\right) \text {. Nyzhne-Serginsk area, “Olenii ruchii” Natonal Park ( } 400 \mathrm{~m}\right) . \\
\text { Fir-rich herb forest with Tilia, Acer, Ulmus, Padus, Pinus. }\end{array}$ \\
\hline 3 & $\begin{array}{l}\text { Bashkiria Republic }\left(54^{\circ} 21^{\prime} \mathrm{N}, 57^{\circ} 30^{\prime} \mathrm{E}\right) \text {. Beloretsk area }(200-700 \mathrm{~m}) \text {. Quercetum herbosum with Ulmus } \\
\text { sp., Tilia, Acer, Corylu, Euonymus, Abies, Pinus. }\end{array}$ \\
\hline 4 & $\begin{array}{l}\text { Bashkiria Republic }\left(54^{\circ} 20^{\prime} \mathrm{N}, 57^{\circ} 32^{\prime} \mathrm{E}\right) \text {. Beloretsk area, Southern Urals Reserve }(250-600 \mathrm{~m}) \text {. Moist } \\
\text { fir-rich herb forest mixed with Quercus, Tilia, Acer, Ulmus. }\end{array}$ \\
\hline 5 & $\begin{array}{l}\text { Bashkiria Republic }\left(53^{\circ} 10^{\prime} \mathrm{N}, 56^{\circ} 32^{\prime} \mathrm{E}\right) \text {. Meleuz area }(300-700 \mathrm{~m}) \text {. Quercetum herbosum with Acer, } \\
\text { Ulmus, Corylus, Betula, Sorbus near the forest-step border. }\end{array}$ \\
\hline
\end{tabular}

Table 2. Clavarioid fungi of the nemoral and hemiboreal zones of the Urals.

\begin{tabular}{|c|c|c|c|c|c|c|}
\hline \multirow{2}{*}{ Species } & \multirow{2}{*}{$\begin{array}{l}\text { Abun- } \\
\text { dance }\end{array}$} & \multicolumn{5}{|c|}{ Locality } \\
\hline & & 1 & 2 & 3 & 4 & 5 \\
\hline \multicolumn{7}{|l|}{$\begin{array}{l}\text { AURICULARIALES } \\
\text { Tremellodendraceae }\end{array}$} \\
\hline Tremellodendropsis tuberosa (Grev.) Crawford & $\mathrm{R}$ & & & $\mathrm{S}$ & & $\mathrm{S}$ \\
\hline \multicolumn{7}{|l|}{$\begin{array}{l}\text { CANTHARELLALES } \\
\text { Clavariaceae }\end{array}$} \\
\hline Clavaria argillaceae Pers. : Fr. & $\mathrm{O}$ & $\mathrm{S}$ & $\mathrm{S}$ & $\mathrm{S}$ & $\mathrm{S}$ & $\mathrm{S}$ \\
\hline C. citriceps Atk. & $\mathrm{R}$ & $\mathrm{S}$ & & $S$ & & \\
\hline C. falcata Pers . : Fr. & $\mathrm{O}$ & $\mathrm{S}$ & $\mathrm{S}$ & $\mathrm{S}$ & $\mathrm{S}$ & \\
\hline C. fragilis Holmsk. : Fr. & $\mathrm{R}$ & $\mathrm{S}$ & $\mathrm{S}$ & $\mathrm{S}$ & $\mathrm{S}$ & \\
\hline C. fumosa Pers. : Fr. & $\mathrm{R}$ & $\mathrm{S}$ & & & $\mathrm{S}$ & \\
\hline C. incarnata Weinm. & $\mathrm{R}$ & & & & $\mathrm{S}$ & \\
\hline C. purpurea O. F. Möll. : Fr. & $\mathrm{R}$ & $\mathrm{S}$ & & $\mathrm{S}$ & $\mathrm{S}$ & \\
\hline C. pullei Donk & $\mathrm{R}$ & & & & $\mathrm{S}$ & \\
\hline C. zollingeri Lev. & $\mathrm{R}$ & & & S & $\mathrm{S}$ & \\
\hline Clavulinopsis aurantio-cinnabarina (Schwein.) Corner & $\mathrm{R}$ & & & $\mathrm{S}$ & & \\
\hline C. biformis (G. F. Atk.) Corner & $\mathrm{O}$ & $\mathrm{S}$ & $\mathrm{S}$ & $\mathrm{S}$ & $\mathrm{S}$ & $\mathrm{S}$ \\
\hline C. corniculata (Pers. : Fr.) Corner & $\mathrm{O}$ & $\mathrm{S}$ & $\mathrm{S}, 11$ & $\mathrm{~S}$ & $\mathrm{~S}, 11$ & \\
\hline C. fusiformis (Fr.) Corner & $\mathrm{R}$ & & & $\mathrm{S}$ & $\mathrm{S}$ & \\
\hline C. helvola (Fr.) Corner & $\mathrm{O}$ & $\mathrm{S}$ & $\mathrm{S}$ & $\mathrm{S}$ & $\mathrm{S}$ & \\
\hline C. laeticolor (Berk. et M. A. Curtis) R. H. Petersen & $\mathrm{O}$ & $\mathrm{S}$ & $\mathrm{S}$ & $\mathrm{S}$ & $\mathrm{S}$ & $\mathrm{S}$ \\
\hline C. luteoalba (Rea) Corner & $\mathrm{R}$ & 11 & & 11 & & \\
\hline C. microspora (Josserand) Corner & $\mathrm{R}$ & $\lg$ & & & $\lg$ & \\
\hline C. subtilis (Pers. : Fr.) Corner & $\mathrm{R}$ & & $\mathrm{S}$ & $\mathrm{S}$ & $\mathrm{S}$ & \\
\hline C. vernalis (Schwein.) Corner & $\mathrm{O}$ & $\mathrm{S}$ & $\mathrm{S}$ & & $\mathrm{S}$ & $\mathrm{S}$ \\
\hline Ramariopsis crocea (Pers. : Fr.) Corner & $\mathrm{O}$ & $\mathrm{S}, 11$ & 11 & $\mathrm{~W}, 11$ & $\mathrm{~S}, \mathrm{~W}, 11$ & 11 \\
\hline R. kunzei (Fr.) Corner & $\mathrm{O}$ & $\mathrm{S}$ & $\mathrm{S}$ & $\mathrm{S}$ & $\mathrm{S}$ & $\mathrm{S}$ \\
\hline R. tenuiramosa Corner & $\mathrm{R}$ & $\mathrm{S}$ & & & 11 & \\
\hline \multicolumn{7}{|l|}{ Clavulinaceae } \\
\hline Clavulina amethystina (Bull. : Fr.) Donk & $\mathrm{O}$ & $\mathrm{S}$ & $\mathrm{S}$ & $\mathrm{S}$ & $\mathrm{S}$ & $\mathrm{S}$ \\
\hline C. cinerea (Bull. : Fr.) J. Schröet & $\mathrm{C}$ & $\mathrm{S}, \mathrm{W}$ & $\mathrm{S}, 11$ & $\mathrm{~S}, \mathrm{~W}$ & $\mathrm{~S}, \mathrm{~W}, 11$ & $\mathrm{~S}$ \\
\hline C. cristata (Holmsk. : Fr.) J. Schröet & $\mathrm{C}$ & $\mathrm{S}$ & $\mathrm{S}$ & $\mathrm{S}$ & $\mathrm{S}, 11$ & $\mathrm{~S}$ \\
\hline
\end{tabular}




\begin{tabular}{|c|c|c|c|c|c|c|}
\hline C. rugosa (Bull. : Fr.) J. Schröet & $\mathrm{O}$ & $\mathrm{S}$ & $\mathrm{S}$ & & $\mathrm{S}$ & \\
\hline \multicolumn{7}{|l|}{ Sparassidaceae } \\
\hline Sparassis crispa (Wulfen : Fr.) Fr. & $\mathrm{R}$ & & & & $\mathrm{W}$ & \\
\hline S. brevipes Krombh. & $\mathrm{R}$ & & & $\mathrm{W}$ & $\mathrm{W}$ & \\
\hline \multicolumn{7}{|l|}{ Typhulaceae } \\
\hline Pistillaria paradoxa (P. Karst.) Corner & $\mathrm{R}$ & & $\mathrm{B}, 11$ & & & \\
\hline *P. quercicola (Imai) Ito & $\mathrm{R}$ & & & $\mathrm{B}$ & $\mathrm{B}$ & \\
\hline Typhula abietina (Fuckel) Corner & $\mathrm{R}$ & 11 & & & 11 & \\
\hline$+T$. anceps $\mathrm{P}$. Karst. & $\mathrm{O}$ & & 11 & 11 & 11 & 11 \\
\hline T. athyrii Remsberg & $\mathrm{O}$ & $\lg$ & & $\lg$ & $\lg$ & \\
\hline T. betae Rostrup & $\mathrm{R}$ & & & & $\lg$ & \\
\hline T. capitata (Pat.) Berthier & $\mathrm{C}$ & $\lg$ & $\lg$ & $\lg$ & $\lg$ & $\lg$ \\
\hline T. caricina P. Karst. & $\mathrm{C}$ & $\lg$ & $\lg$ & $\lg$ & $\lg$ & $\lg$ \\
\hline T. crassipes Fuckel. & $\mathrm{C}$ & $\lg$ & $\lg$ & $\lg$ & $\lg$ & $\lg$ \\
\hline T. culmigena (Mont.et Fr.) J. Schröet & $\mathrm{C}$ & $\lg$ & $\lg$ & $\lg$ & $\lg$ & $\lg$ \\
\hline T. erythropus (Pers. : Fr.) Fr. & $\mathrm{C}$ & 11 & 11 & 11 & 11 & 11 \\
\hline T. euphorbiae (Fuckel) Fr. & $\mathrm{O}$ & & $\lg$ & $\lg$ & $\lg$ & $\lg$ \\
\hline T. fruticum P. Karst. & $\mathrm{R}$ & & & 11 & 11 & \\
\hline T. graminum P. Karst. & $\mathrm{O}$ & $\lg$ & $\lg$ & $\lg$ & $\lg$ & $\lg$ \\
\hline T. gyrans Fr. & $\mathrm{O}$ & $\lg$ & $\lg$ & $\lg$ & $\lg$ & \\
\hline *T. hyalina (Quél.) Berthier & $\mathrm{R}$ & & $\lg$ & $\lg$ & & \\
\hline T. humulina Kuznetsova & $\mathrm{O}$ & $\lg$ & & $\lg$ & $\lg$ & $\lg$ \\
\hline$+T$. incarnata Lassch ex Fr. & $\mathrm{O}$ & $\lg$ & $\lg$ & $\lg$ & $\lg$ & \\
\hline+ T. ishikariensis Imai & $\mathrm{R}$ & $\lg$ & $\lg$ & & $\lg$ & \\
\hline T. lutescens Boud. & $\mathrm{O}$ & 11 & 11 & 11 & 11 & 11 \\
\hline T. micans (Pers. : Fr.) Berthier & $\mathrm{O}$ & $\lg$ & & $\lg$ & $\lg$ & $\lg$ \\
\hline T. muelleri (Sauter) Corner & $\mathrm{R}$ & & $\lg$ & & $\lg$ & \\
\hline T. olivascens Berthier & $\mathrm{O}$ & $\lg$ & & $\lg$ & $\lg$ & $\lg$ \\
\hline T. phacorrhiza (Reichard : Fr.) Fr. & $\mathrm{C}$ & 11 & 11 & 11 & 11 & 11 \\
\hline T. quisquiliaris (Fr. : Fr.) Henn. & $\mathrm{O}$ & $\lg$ & $\lg$ & $\lg$ & $\lg$ & \\
\hline T. sclerotioides (Pers.) Fr. & A & $\mathrm{M}, \lg , 11$ & $\lg , 11$ & 11 & $\lg$ & $\lg$ \\
\hline+ T. setipes (Grev.) Berthier & $\mathrm{C}$ & 11 & 11 & 11 & 11 & 11 \\
\hline T. spathulata (Peck) Berthier & $\mathrm{O}$ & & $\mathrm{B}, 11$ & 11 & 11 & 11 \\
\hline T. sphaeroidea Remsberg & $\mathrm{O}$ & 11 & 11 & 11 & $\mathrm{~B}, 11$ & \\
\hline T. struphiopteridis Corner & $\mathrm{O}$ & $\lg$ & & $\lg$ & $\lg$ & \\
\hline T. subvariabilis Berthier & $\mathrm{R}$ & & & & 11 & \\
\hline T. todei Fr. : Fr. & $\mathrm{O}$ & $\lg$ & $\lg$ & & $\lg$ & \\
\hline T. trifolii Rostrup & $\mathrm{O}$ & $\lg$ & & $\lg$ & $\lg$ & $\lg$ \\
\hline+ T. uncialis (Grev.) Berthier & $\mathrm{C}$ & $\lg$ & $\lg$ & $\lg$ & $\lg$ & \\
\hline T. variabilis Riess & A & $\mathrm{S}, \lg , 11$ & $\lg , 11$ & $\lg$ & $\lg , 11$ & $\lg$ \\
\hline \multicolumn{7}{|l|}{$\begin{array}{l}\text { GOMPHALES } \\
\text { Clavariadelphaceae }\end{array}$} \\
\hline Clavariadelphus fistulosus (Holmsk. : Fr.) Corner & $\mathrm{C}$ & 11 & 11 & 11 & 11 & 11 \\
\hline C. junceus (Alb. et Schwein. : Fr.) Corner & $\mathrm{C}$ & 11 & 11 & 11 & 11 & 11 \\
\hline C. ligula (Schaeff : Fr.) Donk & $\mathrm{O}$ & 11 & & 11 & 11 & \\
\hline C. pistillaris (L. : Fr.) Donk & $\mathrm{R}$ & & $\mathrm{S}$ & & $\mathrm{S}$ & \\
\hline
\end{tabular}




\begin{tabular}{|c|c|c|c|c|c|c|}
\hline C. truncatus (Quél.) Donk & $\mathrm{R}$ & & & & $\mathrm{S}$ & \\
\hline Macrothyphula tremula Berthier & $\mathrm{R}$ & $\lg$ & & $\lg$ & $\lg$ & \\
\hline \multicolumn{7}{|l|}{ Pterulaceae } \\
\hline Lentaria afflata (Lagger) Corner & $\mathrm{R}$ & & $\mathrm{W}$ & $\mathrm{W}$ & $\mathrm{W}$ & $\mathrm{W}$ \\
\hline L. byssiseda (Pers. : Fr.) Corner & $\mathrm{O}$ & 11 & $\mathrm{~W}$ & & $\mathrm{~W}, 11$ & \\
\hline L. delicata (Fr.) Corner & $\mathrm{R}$ & & $\mathrm{W}$ & $\mathrm{W}$ & $\mathrm{W}$ & \\
\hline L. dendroidea (Fr.) J. H. Petersen & $\mathrm{R}$ & 11 & 11 & & 11 & \\
\hline L. mucida (Pers. : Fr.) Corner & $\mathrm{O}$ & W & $\mathrm{W}$ & $\mathrm{W}$ & $\mathrm{W}, 11$ & \\
\hline L. subcaulescens (Rebent.) Rauschert & $\mathrm{R}$ & & & & $\mathrm{W}$ & \\
\hline *L. corticola (Quél.) Corner & $\mathrm{R}$ & & & $(\mathrm{W})$ & & \\
\hline Pterula gracilis (Desm. et Berk.) Corner & $\mathrm{O}$ & 11 & 11 & 11 & 11 & \\
\hline P. multifida (Chevall.) Fr. & $\mathrm{O}$ & $\mathrm{S}$ & $\mathrm{S}, 11$ & $\mathrm{~S}$ & $\mathrm{~S}$ & $\mathrm{~S}$ \\
\hline P. sclerotiicola Berthier & $\mathrm{O}$ & $\lg$ & $\lg$ & $\lg$ & $\lg$ & \\
\hline \multicolumn{7}{|l|}{ Ramariaceae } \\
\hline Ramaria abietina (Pers. : Fr.) Quél. & $\mathrm{R}$ & 11 & & & 11 & \\
\hline R. apiculata (Fr. : Fr.) Donk & $\mathrm{O}$ & $\mathrm{W}$ & $\mathrm{W}$ & $\mathrm{W}$ & $\mathrm{W}$ & \\
\hline R. aurea (Schaeff. : Fr.) Quél. & $\mathrm{O}$ & $\mathrm{S}$ & $\mathrm{S}$ & $\mathrm{S}$ & $\mathrm{S}$ & \\
\hline R. botrytis (Pers. : Fr.) Ricken & $\mathrm{R}$ & & $\mathrm{S}$ & $\mathrm{S}$ & $\mathrm{S}$ & \\
\hline *R. botrytoides $(\mathrm{Peck})$ Corner & $\mathrm{R}$ & & & $\mathrm{S}$ & & \\
\hline *R. broomei (Cotton et Wakef.) R. H. Petersen & $\mathrm{R}$ & & & $\mathrm{S}$ & & \\
\hline R. conjunctipes (Coker) Corner & $\mathrm{R}$ & & & $S$ & $\mathrm{~S}$ & \\
\hline R. corrugata (P. Karst.) Schild & $\mathrm{O}$ & $\mathrm{S}, 11$ & $\mathrm{~S}, 11$ & & $\mathrm{~S}$ & \\
\hline R. deccurens (Pers.) R. H. Petersen & $\mathrm{R}$ & & & $\mathrm{S}$ & & $\mathrm{S}$ \\
\hline R. eumorpha (P. Karst.) Corner & $\mathrm{O}$ & 11 & 11 & 11 & 11 & \\
\hline R. fennica (P. Karst.) Ricken & $\mathrm{O}$ & & $\mathrm{S}$ & $\mathrm{S}$ & $\mathrm{S}$ & $\mathrm{S}$ \\
\hline R. flaccida (Fr.) Ricken & $\mathrm{O}$ & 11 & 11 & 11 & 11 & 11 \\
\hline R. flava (Schaeff. : Fr.) Quél. & $\mathrm{O}$ & $\mathrm{S}$ & $\mathrm{S}$ & $\mathrm{S}$ & $\mathrm{S}$ & $\mathrm{S}$ \\
\hline *R. flavescens (Schaeff.) R. H. Petersen & $\mathrm{R}$ & & & $\mathrm{S}$ & & \\
\hline R. flavobrunnescens (G. F. Atk.) Corner & $\mathrm{R}$ & $\mathrm{S}$ & & $\mathrm{S}$ & $\mathrm{S}$ & \\
\hline R. formosa (Fr.) Quél. & $\mathrm{R}$ & & & $\mathrm{S}$ & $\mathrm{S}$ & \\
\hline R. gracilis (Pers. : Fr.) Quél. & $\mathrm{O}$ & $\mathrm{S}, 11$ & $\mathrm{~S}, 11$ & 11 & $\mathrm{~S}, 11$ & \\
\hline R. holorubella (Atk.) Corner & $\mathrm{R}$ & & & $\mathrm{S}$ & & \\
\hline *R. lutea (Vittad.) Schild & $\mathrm{R}$ & & & $\mathrm{S}$ & & $\mathrm{S}$ \\
\hline R. obtusissima (Peck) Corner & $\mathrm{R}$ & $\mathrm{S}$ & & $\mathrm{S}$ & & \\
\hline R. palmata (Pers.) Quél. & $\mathrm{R}$ & $\mathrm{S}, 11$ & $\mathrm{~S}, 11$ & & $\mathrm{~S}$ & \\
\hline R. rubella (Schaeff.) R. H. Petersen & $\mathrm{R}$ & $\mathrm{W}$ & & & $\mathrm{W}$ & \\
\hline R. rufescens (Fr.) Corner & $\mathrm{R}$ & & $\mathrm{S}$ & & $\mathrm{S}$ & \\
\hline R. strasseri (Bres.) Corner & $\mathrm{R}$ & & & $\mathrm{S}$ & & \\
\hline R. stricta (Pers. : Fr.) Quél. & $\mathrm{O}$ & $\mathrm{W}$ & $\mathrm{W}, 11$ & $\mathrm{~W}, 11$ & $\mathrm{~W}, 11$ & $\mathrm{~W}$ \\
\hline R. subdecurrens (Coker) Corner & $\mathrm{R}$ & & & & $\mathrm{S}$ & \\
\hline R. suecica (Fr. : Fr.) Donk & $\mathrm{R}$ & $\mathrm{S}$ & $\mathrm{S}$ & & $S$ & \\
\hline \multicolumn{7}{|l|}{$\begin{array}{l}\text { HERICIALES } \\
\text { Clavicoronaceae }\end{array}$} \\
\hline Clavicorona pyxidata (Fr.) Doty & $\mathrm{C}$ & $\mathrm{W}$ & $\mathrm{W}$ & $\mathrm{W}$ & $\mathrm{W}$ & $\mathrm{W}$ \\
\hline C. taxophyla (Thom) Doty & $\mathrm{R}$ & & & & $\mathrm{W}$ & \\
\hline
\end{tabular}




\begin{tabular}{|l|c|c|c|c|c|c|}
\hline Hericiaceae & & & & & & \\
\hline$+{ }^{*}$ Ceratellopsis aculeata (Pat.) Corner & $\mathrm{O}$ & & & $\mathrm{lg}$ & & $\mathrm{lg}$ \\
\hline+ C. sagittaeformis (Pat.) Corner & $\mathrm{R}$ & & $\mathrm{M}, \mathrm{lg}$ & & $\mathrm{lg}$ & \\
\hline${ }^{*}$ C. terrigena Berthier & $\mathrm{R}$ & & $\mathrm{S}$ & & $\mathrm{S}$ & $\mathrm{S}$ \\
\hline Mucronella bresadolae (Quél.) Corner & $\mathrm{R}$ & & & & $\mathrm{W}$ & \\
\hline M. calva (Alb. et Schwein. : Fr.) Fr. & $\mathrm{O}$ & $\mathrm{W}$ & $\mathrm{W}$ & & $\mathrm{W}$ & \\
\hline M. flava Corner & $\mathrm{R}$ & \multicolumn{7}{|l|}{} & $\mathrm{W}$ & & \\
\hline \multicolumn{7}{|l|}{} \\
\hline Total families & & 8 & 8 & 10 & 9 & 9 \\
\hline Total genera & & 12 & 13 & 16 & 15 & 12 \\
\hline Total species & & 72 & 69 & 85 & 100 & 43 \\
\hline Species/genus ratio & & 6.0 & 5.3 & 5.4 & 6.7 & 3.6 \\
\hline
\end{tabular}

Note. Abundance estimation: (percentage scale of Stephenson et al. (1993)): "Rare" (R) - species representing less than $0.5 \%$ of the total number of all collection, "Occasional" $(\mathbf{O})$ for $0.5 \%-1.5 \%$ of the total, "Common" $(\mathbf{C})$ for $1.5-3 \%$ of the total, "Abundant" (A) for $>3 \%$ of the total. New species for Russia are marked with asterisk * and from chamber methods are marked by an plus +. Abbreviations of substrate type: $\mathbf{l l}$ - leafy and twigs litter; lg - litter of grasses and ferns on soil; $\mathbf{M}$ - bryophilous; $\mathbf{M y}$ - mycophilous; $\mathbf{S}$ - soil; $\mathbf{W}$ - wood, decayed coarse woody debris $(>10 \mathrm{~cm}$ in diam.); $(\mathbf{W})$ - species which have not been collected in indicated localities but in comparable ecological conditions.

\section{Results}

Altogether 118 species (1300 specimens) belonging to nine families and 15 genera were recorded, and nine species are reported for the first time from Russia. In addition, 10 species belonging to genera Clavaria, Pterula, Ramariopsis, Ramaria and Typhula were collected but remained unidentified. They most probably represent still unknown taxa and will be described and published later. These species are excluded from this paper.

As the Table 2 shows, three families contain over ten species each; the largest being Typhulaceae (35 species), followed by Ramariaceae (30 species), Clavariaceae (22 species), and Pterulaceae (10 species). These families include altogether 99 species, which is $82.5 \%$ of all the species. The rest, 17.5 per cent of the species are distributed between six families, containing one (Tremellodendraceae) to six species (Clavariadelphaceae, Clavicoronaceae, Clavulinaceae, Hericiaceae, Sparassidaceae). The largest genera are Typhula (33 species), Ramaria (30), Clavulinopsis (10), Clavaria (9) and Lentaria (7), respectively. Fifteen species $(12.5 \%)$ were collected only once, 20 species twice $(16.7 \%)$ and 23 species $(19.2 \%)$ three times, respectively.

The species/genus ratio is rather similar in different localities and varies from 5.3 to 6.7 , and only in the southernmost locality (N 5), on the border of the nemoral zone and forest-steppe this coefficient is 3.6. A similar species/genus value (3.5) was observed on the boundary of foreststeppe and southern taiga (Shiryaev 2004).

As Table 2 shows, in the nemoral zone there is a decreasing number of abundant species in comparison with the boreal zone $(1.7 \%$ / 14.6\%) and an increasing number of rare species $(47.8 \%$ / 38.2\%) (see Shiryaev 2004).

The majority $(60 \%)$ of the species are widely distributed, either cosmopolitan or Holarctic, while the rest have naturally a more restricted area of distribution. As mentioned above, the nemoral zone reaches its easternmost points in Ural and as much as 26 per cent of the species are associated solely with the European nemoral ecosystem. For some European species, the Ural is a natural eastern boundary, but some are relicts of Pliocen (survived since ancient times, and were not destroyed by the glacial time (Pleistocen)) and Holocen.

The relicts can be divided into two groups, $a$ : species, which grow in Central and Eastern Europe and Ural but are lacking from Russian plain ("western relicts"), $b$ : species which grow in eastern and southeastern Asia, North America and Ural, but are never collected from regions west of Russian Far East ("eastern relicts"). 
Group $a$ includes species like Ramaria lutea, which primarily grows in broadleaved forests of central and southern Europe, southern Scandinavia and Caucasus but is absent from the Russian plain. In Ural small isolated populations were found in moist, warm areas, where it was association with oak, hazel and pine. Another species, Sparassis brevipes, is predominantly a parasite of mountainous broadleaved forests. It grows in central Europe, in Caucasus and in broadleaved forests of southern central Ural. $R a$ maria broomei often grows in broadleaved and mixed forests but also in light forest edges and steep slopes in southern Scandinavia and central Europe. Again, it is lacking from east European plain but appears in southern Ural again, where it was found in oak-pine forest.

Group $b$ includes species like Pistillaria quercicola, which main distribution area is in the broadleaved forests of Japan and southern parts of Russian Far East (e.g., Ussury Reserve). In southern Ural it was found in broadleaved forests of Bashkiria. It is possible to add Clavulinopsis aurantiocinnabarina to this group. Its main distribution area may be in eastern Asia and in the far East, but it also grows on the Himalayas, and is widespread in the nemoral zone of North America and even penetrates to the tropical areas in the south. Besides southern Ural it has separate relict locations in south Siberia on the shores of Lake Baikal (Buryat Republic) and Lake Teletskoe (Altai Republic).

All the relicts and rare species were found on western slopes of south Ural in Bashkiria Republic, between the mountains Akbulyakarka (54 $\left.22^{\prime} \mathrm{N}\right)$ and Maly Nakas $\left(52^{\circ} 30^{\prime} \mathrm{N}\right)$.

In this study most of the species grew on soil, wood and leaf- or grass-litter. The decayed litter is the most common substrate numbering 63 species, including 45 obligate and 18 facultative species, like Typhula variabilis with 41 field collections, T. culmigena (36), T. erythropus (33) and T. uncialis (30), respectively. Also species with large fructifications were fairly common on litter (Typhula setipes, T. sclerotioides). Of the soil-inhabiting 51 species, 41 are obligate and 10 facultative, and they are rare or uncommon (1-10 collections), except the widespread Clavaria argillacea, Clavulina cinerea, C. cristata and Ramaria aurea. The number of wood-decaying species is rather low: 21 species of which six are facultative. This group contains species like Clavicorona pyxidata and Ramaria apiculata, and as a whole the species of this wood-inhabiting group can be considered as rare or uncommon.

The moist chamber method provoked seven species, e.g., Ceratellopsis aculeata, Typhula incarnata and T. setipes.

The most common pathogens on herbs and trees were Sparassis crispa, S. brevipes, Typhula betae, T. incarnata, T. ishikariensis and T. trifolii.

In this material the highest biological diversity at genus level was in the Locality 3 (Quercetum herbosum) with 16 genera and the lowest ones in the Localities 1 and 5 (spruce dominated herb-rich forest and Quercetum herbosum near forest-steppe border) with 12 genera. The richest species composition was found in Locality 4 (fir dominated herb-rich broadleaves forest) with 101 species and 15 genera. The moist or humid oak forests harbor the most diverse species composition, followed by the spruce forests and dry oak dominated ecosystems.

The Ural species can roughly be divided into three groups according to their habitat requirements: (a) old-growth (virgin) forests species, (b) species of commercially managed forests, which may be old, and (c) species of human influenced habitats.

The first group (a) consists of Clavaria pullei, C. zollingeri, Clavulinopsis microspora, Clavariadelphus truncatus, Lentaria mucida, $L$. subcaulescens, Pistillaria quercicola, Ramaria botrytoides, $R$. broomei, $R$. decurrens, $R$. fennica, $R$. lutea, $R$. rubella, $R$. strasseri, $R$. subbotrytis, $R$. subdecurrens, $R$. subtilis, Sparassis brevipes and $S$. crispa.

To the second group (b) belong Ceratellopsis terrigena, Clavulinopsis fusiformis, C. laeticolor, Clavariadelphus pistillaris, Clavicorona taxophila, Lentaria afflata, Macrotyphula tremula, Ramaria flavescens, $R$. flavobrunnescens, $R$. mutabilis, $R$. obtusissima, Ramariopsis crocea and Tremellodendropsis tuberosa.

In the last group (c) we find Lentaria corticola, Typhula betae, T. uncialis and T. variabilis.

\section{New and rare species for Russia}

Ceratellopsis aculeata (Pat.) Corner, Ann. Bot. Mem. 1: 198. 1950.

New to Russia. Fruit body simple $0.5-2.0 \mathrm{~mm}$ long, thread- or needle-like, when young apically sterile, later fertile, white; stem shorter than 
club, 0.2-0.4 mm high. Spores 3.6-6.3 × 1.9-3.2 $\mu \mathrm{m}$, ellipsoid, weakly amyloid; basidia 4-spored; hyphae thin- or thick-walled, clamps present; cystidia absent.

Specimens examined: Russia. Bashkiria Rep., Mesyagutovo area, lake shores and moors, on decaying Cladium mariscus, 8.X.1999 Shiryaev 872, 873, 889, 902; Beloretsk area, lake near Inzer river, on decaying Scirpus lacustris, 8.X.2001 Shiryaev 2619 and moors, on decaying Scirpus lacustris, 4.IX.2002 Shiryaev 3147, 3148; Uchali area, irrigation canal, on decaying leaves of Scirpus radicans, 5.IX.2002 Shiryaev 3166, 3167. Chelyabinsk Reg., Asha area, moor, on decaying Alisma plantago-aquatica, 24.VIII.2002 Shiryaev 3081.

Ceratellopsis terrigena Berthier, Bull. Soc. Linn. Lyon 43: 188. 1974.

New to Russia. Fruit bodies up to $2.7 \mathrm{~mm}$ long, whitish, basally brownish, thread- or spindle-like with sterile apex; basidia 4-spored; hyphae without clamps; cystidia present; spores non-amyloid, $3.5-5.2 \times 1.8-2.1 \mu \mathrm{m}$. The specimens correspond to the description and figure given by Berthier (1976).

Specimens examined: Russia. Sverdlovsk Reg., NyzhneSerginsk area, on soil under Tilia cordata and Ulmus laevis, 3.IX.2001 Shiryaev 2502. Bashkiria Rep., Beloretsk area, on soil under Ulmus scabra and Acer platanoides, 8.X.2001 Shiryaev 2635; Meleuz area, on soil under Acer platanoides, Quercus robur, Corylus avellana and Euonymus verrucosa, 11.X.1999 Shiryaev 914, 915 and on soil under Quercus robur, Tilia cordata, Malus praecox, 31.VIII.2002 Shiryaev 3112.

Lentaria corticola (Fr.) Corner, Ann. Bot. Mem. 1: 440.1950.

New to Russia. Fruit bodies 1-4 mm long, simple or dichotomously branched, sometimes with short branches with sterile apices, orange yellow, caespitose, without distinctly delimitated stem towards the narrow, fertile base; basidia $13-25 \times 3.7-4.2 \mu \mathrm{m}$, narrowly clavate, with four sterigmata; hyphae thin-walled, clamped, sometimes with crystals; cystidia none; spores ellipsoid, 3.7-4.8 ×2.4-3.1 $\mu \mathrm{m}$, smooth, mostly amyloid, with up to $1 \mu \mathrm{m}$ long apiculus.

The subgenus Lentariopsis to where L. corticola belongs, has two other species, viz. L. afflata and L. subcaulescens, but their fruit bodies are differently coloured, more branched and their spores are larger.

Lentaria corticola was also collected in Crimea, Ukraine, on a Pinus pallasiana stump and it fits in all respects with the Bashkirian collection.

Specimens examined: Russia. Bashkiria Rep., Ufa town, in the park, on bark of dead erect Pinus sylvestris, 10.X.1999 Shiryaev 907. Ukraine. Crimea, Yalta, slope of Ai-Petri Mountain., on stump of Pinus pallasiana, 26.IX.2003 Shiryaev 4425

Pistillaria quercicola (Imai) Ito, Myc. Fl. Japan 2: 80.1955.

New to Russia. Fruit bodies $6-11 \mathrm{~mm}$ high, single or in groups, white, drying yellowish to brownish; head 5.5-8.5 mm long, cylindrical, apex sometimes truncate; stem shorter than the club, 1.5-2.5 mm long, whitish, hairs absent; crystals rarely present on hyphae, indistinct; basidia 4-spored; spores ellipsoid, 3.2-3.8 $\times 1.5-$ $2.2 \mu \mathrm{m}$.

Some authors (Corner 1970, Berthier 1976) have the opinion that $P$. quercicola is a complex of species, which includes species like $P$. albobrunnea Pat. and P. pusilla Fr. In my opinion, $P$. pusilla is a distinct, and common species in Ural. Its fruit bodies are white and small, measuring 1-4 $\mathrm{mm}$. The spores, on the contrary, are large, $6.3-8.1 \times 4.0-4.8 \mu \mathrm{m}$, and it grows solely on leaves of deciduous trees. I have collected this species also in Far East Russia, and it is in all respects similar to the Ural specimens and is not conspecific with $P$. quercicola. Pistillaria albobrunnea, however, is closer to $P$. quercicola in having 2-6 mm long fruit bodies, white club, and spores measuring 3.2-4.2 $\times 1.0-2.0 \mu \mathrm{m}$. However, there are some differences, like the brownish stem, which is distinctly delimited from the club. Moreover, it grows only on decaying leaves of hardwoods. All in all, I have never before seen a species of Typhulaceae, growing on wood (not twigs) or bark, but also on decaying leaves. The collecting sites of Pistillaria quercicola were all very moist, in oak dominated forests mixed with fir. These forests are situated in the warmest areas of Ural and they also contain the highest number of relict grasses of nemoral zone, as well as relicts from eastern Asia.

Specimens examined: Russia. Bashkiria Rep., Beloretsk area, Southen Urals Reserve, on decaying bark of Quercus ruber, 3.X.2000 Shiryaev 1181, 1182 and 8.X.2001 Shiryaev 2649, 2670. Far East: Primorski Krai, Ussury Reserve, decaying bark of Quercus mongolica, 26.VII.2003 Shiryaev 3817. 
Ramaria botrytoides (Peck) Corner, Ann. Bot. Mem. 1: 562. 1950.

Reported earlier from Russia by Govorova (1999). Fruit bodies orange yellow to rosy orange coloured; juvenile tips pinkish, at maturity brownish. Clamps common at the base of basidia and in the subhymenium, absent or occasional elsewhere. Spores 6.3-11.1 × 3.4-4.8 $\mu \mathrm{m}$, almost smooth or finely rough with small warts.

Petersen (1967) described the hyphae of Peck's type to be sometimes clamped and the spores measuring 8.4-10.1 × 3.6-4.6 $\mu \mathrm{m}$, with longitudinal rows of low, obscure warts. According to Franchi \& Marchetti (2001) the spores are 6-11($11.2) \times(2.8-) 3.2-5.3(-5.6) \mu \mathrm{m}$, and according to Corner (1970) 7.0-11.5 × 3.5-4.5 $\mu \mathrm{m}$.

The collecting sites in Ural are on southern slopes in herb rich oak-pine forests. Ramaria botrytoides seems to be a rare species in Russia, and is found only in nemoral mountainous regions.

Specimens examined: Russia. Bashkiria Rep., Beloretsk area, near an oak stump, on soil mixed with decaying pieces of wood and oak-pine litter on lime stone soil, 7.X.2000 Shiryaev 4977, 4978; Krasnousolsk area, Takaty Range, on clay-stone soil in the oak-pine forest not so far from a brook, 10.X.2000 Shiryaev 1112, 1183. Caucasus, Krasnodar Reg., Caucasus Reserve, surroundings of Guzeripl, on humus in Abies-Fagus forest 14.IX.2003 Shiryaev 4338.

Ramaria broomei (Cotton et Wakef.) R. H. Petersen, Bibl. Mycol. 79: 53. 1981.

New to Russia. Fruit bodies olivaceous ochre or grayish ochre, finally blackening; tips retaining orange ochre or brownish orange, the whole fungus turning dark vinaceous brown when bruised; spores 13.2-17.2 × 5.1-7.2 $\mu \mathrm{m}$.

The spores are similar in Swedish samples, viz., (12-)14-16 × (5-)6-7 $\mu \mathrm{m}$ (Nitare 2002) and fit well also with those given by Parmasto (1965), 12.5-20 × 5-8 $\mu \mathrm{m}, \mathrm{R}$. H. Petersen (1981), 13.5-18.5 × 5-7.5 $\mu \mathrm{m}$, and J. H. Petersen (1997), $13-19 \times 5-7.5 \mu \mathrm{m}$.

This species belongs to subgenus Echinoramaria Corner (Petersen 1981) and its characteristics are e.g. the long spores (up to $20 \mu \mathrm{m}$ ) “....with ornamentation of numerous thick-based spines up to $3.0 \mu \mathrm{m}$ long, rarely as short plates, but sometimes arranged in irregular rows" (Petersen 1981). Other characteristics are constantly 2-spored basidia and brown, dark-brown or black colour of fruit bodies. Other dark-coloured species close to
R. broomei, are R. americana (Corner) Petersen and $R$. cokeri Petersen (Petersen 1981; Govorova 2002) which, however, never have only 2 -spored basidia, and have never an orange hue.

Specimens examined: Russia. Bashkiria Rep., Beloretsk area, Ilmerdak Range, on soil on southern slope of an oak forest, 15.IX.1999 Shiryaev 837, 838. Caucasus, Krasnodar Reg., Tuapse area, on humus in Quercus-Castanea forest 15.X.2003 Shiryaev 4911; Caucasus Reserve, Hosta, on humus under Fagus orientalis, Quercus iberica and Taxus baccata 18.X.2003 Shiryaev 4954.

Ramaria flavescens (Schaeff.) R. H. Petersen, Amer. J. Bot. 61: 740. 1971.

Reported earlier from Russia by Govorova (1999). Fruit bodies up to $14 \mathrm{~cm}$ high and broad, branching 2-6 times, branches pinkish salmon to pinkish buff; apices pale yellow, lemon chrome to orange yellow or concolorous with branches; taste mild. Stem large, up to $4 \times 3 \mathrm{~cm}$, tomentose downwards, white below soil level, cream-coloured above. Tramal hyphae in stipe 4.2-8.6 $\mu \mathrm{m}$ in diam., hyaline, thin- or thick-walled, clamped; hyphae of stipe surface comparable, but sometimes narrow, only $1.7 \mu \mathrm{m}$ wide. Basidia clavate, basally clamped, 50.5-54.5 × 9.3-12 $\mu \mathrm{m}$, 4-spored. Spores pale-yellow in mass, ellipsoid, contents weakly cyanophilous, with low coarse warts and delicate meandering ridges, 9.3-12.8 $\times 4.7-5.9 \mu \mathrm{m}$.

The description of spores fits well with that given by Jülich (1984), 8.5-13.0 x 4.5-6 $\mu \mathrm{m}$, Petersen (1989), (9.4-)10.4-12.5 × 4.3-5.9 $\mu \mathrm{m}$ and Petersen (1997), 10-13 × 4-5.5 $\mu \mathrm{m}$. The collecting site in Ural is an oak dominated old-growth forest, which has apparently never been cut. It also has many nemoral vascular plants relicts, mosses and fungi of other groups. The records from Russia so far give the impression that Ramaria flavescens is a nemoral species with a disjunctive distribution in Eurasia. It is one of the most common Ramaria species in Europe (Franchi \& Marchetti 2001), but rare in Russia.

Specimens examined: Russia. Bashkiria Rep., Beloretsk area, southern slope of Ilmerdak Range, on soil in oak forest, 16.IX.1999 Shiryaev 843, 855. Caucasus, Krasnodar Reg., Caucasus Reserve, Hosta, on soil under Taxus baccata, Fagus orientalis and Abies nordmanniana, 19.VI. 2004 Shiryaev 4972.

Ramaria lutea (Vittad.) Schild, Persoonia 9: 409. 1977. 
New to Russia. Fruit bodies up to $10 \mathrm{~cm}$ high and broad, stipe $4 \times 2 \mathrm{~cm}$, sphaeropedunculate, without branch lets; flesh whitish, marbled, with moist or gelatinous areas. Branches thin, more or less bend, terete, pale yellow to sulphur yellow, when old dull ochraceous; flesh whitish, marbled to gelatinous; smell absent; tramal hyphae branched, 5-15 $\mu \mathrm{m}$ wide, hyaline, thin-walled, tightly adherent, clampless; spores ellipsoid, $7.3-10.7 \times 3.9-4.7 \mu \mathrm{m}$, with some small, discrete warts without any clear orientation.

The spore-size given by J. H. Petersen (1997), $7.5-11 \times 4.0-4.5 \mu \mathrm{m}$, is closer to my observations, than that given by Schild (1977), (5.5-) $6.5-10.5(-10.8) \times 3.2-5.5 \mu \mathrm{m}$.

Microscopically $R$. lutea is very similar to $R$. flavo-saponaria, which are easily separated, however, by fruit body height and shape. Ramaria flavo-saponaria has a small stipe with numerous clusters of branch lets. A very similar species, R. flava (Petersen 1974, 1989), has clear lemon yellow colour, non-rooting stipe, non-gelatinous flesh, basally clamped basidia, and somewhat larger spores, $11.8-14.8 \times 5.2-5.9 \mu \mathrm{m}$.

Specimens examined: Russia. Bashkiria Rep., Beloretsk area, on soil in oak-fir dominated forest, southern slope of hill, 8.X.2001 Shiryaev 2640, 2641. Caucasus, Krasnodar Reg., Caucasus Reserve, western slope of Abago Range, on soil in beech-fir forest, $1400 \mathrm{~m}$ a. s. 1. 11.X.2004 Shiryaev 4918.

Ramaria mutabilis Schild et R. H. Petersen, Bibl. Mycol. 79: 149. 1981.

Reported earlier from Russia by Govorova (2002). Fruit body small, less than $8 \mathrm{~cm}$ high and $4 \mathrm{~cm}$ broad, repeatedly branched, very variable in shape from fusiform to broadly obovate; stipe base up to $15 \mathrm{~mm}$ broad, with white mycelium and rhizomorphs extending a few $\mathrm{mm}$ to several centimeters and sometimes interconnecting several fruit bodies; rhizomorphs and mycelium mealy, occasionally discrete and rope-like, remaining off-white in drying; stipe 3-15 mm long, slender and well-defined, longitudinally ridged, the ridges continuing to the major branches, white below the basal mycelium, brown to olive-brown above the basal mycelium, occasionally clearly greenish especially in stout-stiped fruit bodies, when handled or picked, turning slowly reddish brown.

Major branches up to $4 \mathrm{~mm}$ thick, usually flattened or longitudinally channeled or ridged, erect; smaller branches similar, but axes round- ed to lunate; hymenium irregularly unilateral, the fertile areas on inner or upper branch surfaces, especially above axes; colour of branches dull olive-brown to yellowish-olive-brown; all branches becoming extremely fragile on drying; apices minute, digitate, when young and fresh creamy yellow to ochraceous olive, in age becoming duller to a little blackish.

Odor mild, taste bitter or acrid; when dried without odor.

Hyphae of rhizomorphs thin-walled, hyaline; ampullaceous clamps up to $11 \mu \mathrm{m}$ broad; hyphae of branch trama to $6 \mu \mathrm{m}$ in diam., thin-walled, somewhat inflated, clamped, hyaline. Basidia 40-58 × 5-6.5 $\mu \mathrm{m}$, narrowly clavate, clamped, hyaline. Hymenium thickened.

Spores ovoid to ellipsoid, adaxially slightly flattened, with one guttule, thin-walled, covered with up to $0.7 \mu \mathrm{m}$ long spines which may be forked; hilar appendix eccentric, papillate. The spores of the Ural and Altai material, (5.2-)5.4$7.4(-7.7) \times(3.1-) 3.3-4(-4.2) \mu \mathrm{m}$ are in agreement with the measurements given by Petersen (1981), viz. $5.5-7.5 \times 3.3-4.1 \mu \mathrm{m}$.

In the Caucasian material the spores are slightly larger, $(4.8-) 5-7.8(-8.1) \times(2.8-) 3.1-4.1(-$ 4.3) $\mu \mathrm{m}$, about the same size given by Schild (see Franchi \& Marchetti 2001: 72), viz. (4.5-)4.8$8(-8.3) \times(2.4-) 2.9-4.2(-4.4) \mu \mathrm{m}$

Ramaria mutabilis seems to be a Holarctic species, and is reported from Italy, Hungary, Switzerland (Jülich 1984), Far East (Govorova 2002), the Himalayas, and western and eastern North America (Petersen 1981). In Russia, $R$. mutabilis is a rare species collected only in mountainous regions with nemoral forests dominated by conifers.

Specimens examined: Russia: Bashkiria Rep., Beloretsk area, western slope of Ilmerdak Range, on soil in forest with fir, oak, maple and pine, 17.IX.1999 Shiryaev 860; Sverdlovsk Reg., Ekaterinburg city, Botanical Garden, on soil under pine, maple and Juglans manshurica Maxim., 18.IX. 2004 Shiryaev 4966; Altai Rep.: southern coast of Teletskoe Lake, Kyga river area, on humus under fir, Pinus sibirica and Populus tremula 20.IX.1967 (coll. Kazantseva) Shiryaev 807; Caucasus, Krasnodar Reg., surroundings of Guzeripil, on soil in forest with Abies, Pinus and Quercus, 17.IX.2003 Shiryaev 4315, 4933. Russian Far East: Primorsk Reg., Sihote-Alin Reserve, on humus in forest with Picea ajanensis, Abies nephrolepis and Acer mono, 17.08.1995 Bogacheva (VLA M-1298.

Ramaria subbotrytis (Coker) Corner, Ann. Bot. Mem. 1: 625. 1950. 
Reported earlier from Russia by Govorova (2004). This species is easily recognized by the deep coral pink to salmon pink yellowish colour. Hyphae simple septate, cystidia none. Spores, small, narrow and brown violet in mass.

My specimens fit well with original description of Corner (1950). Ramaria subbotrytis forma flavipes Franchi \& Marchetti (2001) differs from $R$. subbotrytis only in having golden yellow stem just above the substrate.

Ramaria subbotrytis is widely distributed in northern hemisphere and reported from Slovakia, Switzerland, Japan (Parmasto 1965), the Himalayas (Thind 1961) and western and eastern North America (Coker 1923; Corner 1950; Petersen 1967), but seems to prefer temperate or hemiboreal subzone and mountainous regions. As mentioned by Corner (1950) R. subbotrytis may be a rather rare species and the Russian material confirms this.

Specimens examined: Russia: Bashkiria Rep., Beloretsk area, Southern Ural Reserve, surroundings of Inzer village, on humus in Abies-Quercus-Acer forest, $680 \mathrm{~m}$ a. s. 1., 11.IX.1997 Shiryaev 581; Sverdlovsk Reg., Achit area, mixed forest with fir and oak, 8.X.1999 Shiryaev 1007, 1008. Caucasus, Krasnodar Reg., Caucasus Reserve, eastern slope of Lagonaki Platou, on humus in forest with Fagus orientalis, Quercus iberica and Abies nordmaniana, $1500 \mathrm{~m}$ a. s. 1., 16.IX.2003 Shiryaev 4388.

Ramaria subtilis (Coker) Schild, Zeit. Myc. 48: 119. 1982.

New to Russia. According to the description by Schild (1982) the Ural specimens are closer to $R$. subtilis var. subtilis Schild in having fruit bodies $63-90 \mathrm{~mm}$ high and $45-60 \mathrm{~mm}$ wide; stipe 18-30 × 10-20 mm, whitish; major branches lilac-yellowish, pale yellow to cream coloured; tips concolorous with the branches. Spores (9.6-)10-13.8(-14.1) × (3.6-) 3.8-5.2(5.5) $\mu \mathrm{m}$ (in Schild 1982, 10.1-14.4 × 3.9-5.5 $\mu \mathrm{m}$ and in Franchi \& Marchetti 2001, (9.3-)9.9-12.8 $\times(4.1-) 4.6-5.8 \mu \mathrm{m})$, generative hyphae up to 21 $\mu \mathrm{m}$ wide, without clamps. Ramaria subtilis var. crassifolia Schild has larger, pale yellow fruit bodies $(100-130 \times 75-115 \mathrm{~mm})$; tips concolorous with the branches or citrine yellow; spores (8.8-)9.6-16 × 4.4-6.7(-6.9) $\mu \mathrm{m}$ (Franchi \& Marchetti 2001).

Ramaria subtilis seems to prefer broadleaved forests but exists also in mixed forests. It may be a holarctic species which has been collected in
Spain, Switzerland, Germany, Italy (Jülich 1984) and North America (Coker 1923).

Specimens examined: Russia: Bashkiria Rep., Beloretsk area, Ilmerdak Range, on humus in broadleaved forest with oak, maple and pine, 3.IX.1997 Shiryaev 487; Russian Far East: Primorsk Reg., Ussuri Reserve, mixed forest with Quercus mongolica, Acer mono, Abies holophylla, Carpinus cordata and Betula costata, 19.VIII.2003 Shiryaev 4016.

Typhula hyalina (Quél.) Berthier, Bull. Soc. Linn. Lyon 43: 186. 1974.

New to Russia. Fruit bodies less than $1.5 \mathrm{~mm}$ high, club semiglobose or slightly conical, hyaline; stem hyaline, widened just below the club and at the base, smooth or with a few hairs, up to $74 \mu \mathrm{m}$ long; hyphae clamped; basidia clavate, 47-64 × 7-8 $\mu \mathrm{m}$; spores ellipsoid, 8.8-11.6 $\times$ 3.5-4.2 $\mu \mathrm{m}$. Berthier's (1974) measurements of the spores, 9-10-12 × 3.75-4-4.25 $\mu \mathrm{m}$, is almost equal of mine, like in Hansen and Knudsen

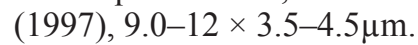

The habitats of T. hyalina are moist northwestern or western slopes or near brooks on hill tops.

Specimens examined: Russia. Sverdlovsk Reg., NyzhneSerginsk area, "Oleny ruchi" National Park, on decaying Eleocharis sp., 5.X.2001 Shiryaev 2579 and on decaying Juncus bufonus, 29.IX.2002 Shiryaev 3307. Bashkiria Rep., Beloretsk area, decaying Melica nutans, 5.X.2002 Shiryaev 3361, 3362. Caucasus, Krasnodar Reg., Caucasus Reserve, northern slope of Fisht Mountain., $1300 \mathrm{~m}$ a. s. 1., on decaying Juncus bufonius and Melica nutans, 18.IX.2003 Shiryaev 4931, 4950.

Acknowledgements: I am deeply grateful to all my friends and colleagues for invaluable assistance in the field, for interesting communications and discussions. Special thanks are due to my friends, Dr. Heikki Kotiranta (Helsinki), Henning Knudsen, Peer Corfixen (both Copenhagen), Nadya Ushakova and Konstantin Fefelov (both Ekaterinburg). In addition, I owe my thanks to Dr. Olga K. Govorova (Vladivostok) for the information of some Ramaria species in Far East. My sincere thanks are extended to my supervisor Prof. Victor Mukhin, for giving me the opportunity to study and work with him and also to Acad. Pavel L. Gorchakovsky (Ekaterinburg) for his help connected with the problems of historical phytogeography of Ural. I am particularly grateful to Heikki Kotiranta for the revision of the text. The English language was reviewed by Mikako Sasa, also she is warmly thanked. This work was supported by the Russian Foundation for Basic Research (grant N 02-05-64577). 


\section{References}

Bedenko, Е.Р. [Беденко Э. П.] 1985: Ad floram macromycetum Alauniae Notula. I. - Nov. Sist. Nizsh. Rast. 22: 110-115 [In Russian].

Berthier, J. 1976: Monographie des Typhula Fr., Pistillaria Fr. et genes voisins. - Bull. Mens. Soc. Linn. Lyon. 45: 233 pp.

Bondartseva, M.A., Zmitrovich, I.V. \& Lositskaya, V.M. [Бондарцева, М.А., Змитрович, И.В., Лосицкая, B.M.] 1999: Aphyllophoroid and heterobasidioid fungi of Leningrad region. - In: Balashov, N.B. \& Zavarzin, A.A. (eds.): Biodiversity of Leningrad region (Algae, Fungi, Lichens, Musci, Invertebrates, Vertebrates, Fishes). St. Petersburg: 141-173. [In Russian].

Coker, W.C. 1923: The Clavarias of the United States and Canada. - Univ. North. Carolina Press, Chapel Hill. $209 \mathrm{pp}$.

Corner, E.J.H. 1950: A monograph of Clavaria and allied genera. - London. Oxford Univ. Press. 740 pp.

Corner, E.J.H. 1970: Supplement to "A monograph of Clavaria and allied genera". - Nova Hedwigia 33: $1-299$.

Czerepanov, S.K. 1995: Vascular plants of Russia and adjacent states (the former USSR). - Cambridge University press. $516 \mathrm{pp}$.

Davidkina T.A., Ivanov A.I., Komirnaya O.N. [Давыдкина Т.А., Иванов А.И., Комирная О.Н.] 1989: Novitates de Aphyllophoralibus et Gasteromycetibus elevationis Volgensis. - Nov. Sist. Nizsh. Rast. 26: 60-63 [In Russian].

Dunaev, E.A., Barsukova, T.N. [Дунаев, Е.А., Барсукова, T.H.] 1999: Clavarioid fungi of Moscow area. - Moscow. MosgorSUN. 40 pp. [In Russian].

Franchi, P., Marchetti, M. 2001: Introduzione allo studio genere Ramaria in Europa, chiavi per la determinazione delle specie, principali riferimenti bibliografici. - Pubbl. M. Canduso. 104 pp.

Gorchakovsky, P.L. [Горчаковский, П.Л.] 1968: The European broad-leaved forest plants at their eastern distribution limits. - Academia Nauk USSR. Ural Division. N 59: 207 pp. [In Russian].

Gorchakovsky, P.L. [Горчаковский, П.Л.] 1975: The plant world of high mountain of the Ural. - Academia Nauk USSR. Moscow. Nauka. 274 pp. [In Russian].

Govorova, O.K. [Говорова, O.К.] 1999: Clavarioid fungi from surroundings of the city Vladivostok. - Micol. Fitopatol. 33: 228-232. [In Russian]

Govorova, О.К. [Говорова, О.К.] 2002: Species of the genus Ramaria (subgenus Echinoramaria) in the Far East of Russia. - Micol. Fitopatol. 36: 24-30. [In Russian].

Govorova, О.К. [Говорова, О.К.] 2004: Cantharelloid, Clavarioid and Thelephoroid fungi of nature reserves of the Primorsky Territory. - Nov. Sist. Nizsh. Rast. 37: 71-77. [In Russian].

Hansen, L. \& Knudsen, H. (eds.) 1997: Nordic Macromycetes 3. Heterobasidioid, aphyllophoroid and gastromycetoid Basidiomycetes. - Nordsvamp. Copenhagen. $444 \mathrm{pp}$.

Härkönen, M. 1977: Corticolous myxomycetes in three different habitats in southern Finland. - Karstenia 17: 19-32.
Hoshino, T., Tkachenko, O.B., Kiriaki, M., Yumoto, I. \& Matsumoto, N. 2004: Winter damage caused by Typhula ishikariensis biological species I on conifer seedlings and hop roots collected in the Volga-Ural regions of Russia. - Can. J. Plant Pathol. 26: 391-396.

Jülich, W. 1984: Die Nichtblätterpilze, Gallertpilze und Bauchpilze. - Jena: VEB Gustav Fisher Verlag. 626 pp.

Nitare, J. 2002: Svartnande fingersvamp Ramaria broomei i Sverige. - Jordstjarnan 23: 12-19.

Parmasto, E.H. [Пармасто, Э.X.] 1965: Key to the Clavariaceae of USSR. - Leningrad Acad. Sc. USSR. 165 pp. [In Russian].

Petersen, R.H. 1967: Type studies in clavarioid fungi I. The taxa described by Charles Horton Peck. - Mycologia 59: 767-802.

Petersen, R.H. 1972: Notes on clavarioid fungi XII. Miscellaneous notes on Clavariadelphus, and a new segregate genus. - Mycologia 64: 137-152.

Petersen, R.H. 1974: Contribution toward a monograph of Ramaria I. Some classic species redescribed. - Amer. J. Bot. 6: 739-748.

Petersen, R.H. 1981: Ramaria subgenus Echinoramaria. - Bibl. Mycol. 79: 1-261.

Petersen, R.H. 1989: Contributions towards a monograph of Ramaria VII. Some taxa sheltered under the name Ramaria flava. - Persoonia 14: 23-42.

Pilát, A. 1958: Übersicht der europäischen Clavariaceen unter besonderer Berücksichtingung der tschechoslowakischen Arten. - Sborn. Nar. Mus. Praze 14: 129-255.

Potatosova, E.G. [Потатосова Е.Г.] 1960: The genus Typhula of USSR. - Bot. J. 45: 567-572. [In Russian].

Schild, E. 1977: Clavaria lutea Vitt., eine eigene Art. - Persoonia 9: 409-416.

Shiryaev, A.G. 2004: Clavarioid fungi of Ural. I. Boreal zone. - Micol. Fitopatol. 38: 59-72.

Sjörs, H. 1963: Amphi-Atlantic zonation, nemoral to arctic. North Atlantic biota and their history. - Oxford. 620 pp.

Spirin, V.A. [Спирин, B.A.] 2003: Aphyllophoroid fungi of Nizhegorod region: biodiversity and ecology. - Thesis Ph. D., St. Petersburg: 27 pp. [In Russian]

Stepanova-Kartavenko, N.T. [Степанова-Картавенко, H.T.] 1967: The Aphyllophoroid fungi of Ural. - Academia Nauk SSSR, Ural filial. 50: 1-296. [In Russian].

Stephenson, S.L., Kalyanasundaram, I. \& Lakhanpal, T.N. 1993: A comparative biogeographical study of myxomycetes in the mid-Appalachians of eastern North America and two regions of India. - J. Biogeogr. 20: 645-657.

Thind, K. 1961: The Clavariaceae of India. - Council Agric. Res., New Dehli: 197 pp. 